ISSN 2078-6441. Вісник Львівського університету. Серія географічна. 2013. Випуск 42. С. 311-316. Visnyk of the Lviv University. Series Geography. 2013. Issue 42. P. 311-316.

911.3:32

кс н клярськ

ьвівський н ціон льний університет імені в н вул. . орошенк, 41, 79000, ьвів, кр їн

бгрунтов но з с ди держ вної регіон льної політики для різно спектної інтегр ції н селення прикордонних етнічно неоднорідних регіонів у з г льноукр їнське середовище. озроблено стр тегію г рмоніз ції етнополітичних вз ємин у прикордонні.

лючові слов : регіон льн політик, прикордонні р йони, етнополітичні вз ємини, інтегр ція в $з$ г льноукр їнське середовище.

продовж б г тьох років прикордонні регіони кр їни розвив лись під впливом нег тивних, з погляду соці льно-економічного розвитку чинників. огр ничність, що в р дянський період ототожнюв л сь 36 р'єрністю, периферійністю, штучне г льмув ння т непропорційність господ рського розвитку обл стей зумовили низку проблем суспільно-політичного х р ктеру. олітичну ситу цію з вжди ускл днюв в етнон ціон льний чинник: с ме в прикордонні зосереджені основні р йони комп ктного розселення етнон ціон льних меншин в кр їні. прикл д, у пригр ничній смузі чотирьох дміністр тивних $\mathrm{p}$ йонів к рп тської обл. прожив $є$ пон д $90 \%$ усіх угорців кр їни. умуни комп ктно розселені у 48 н селених пункт х ернівецької обл., т кож у прикордонних сел $\mathrm{x}$ ячівського $\mathrm{i}$ хівського $\mathrm{p}$ йонів к рп ття. овоселицькому i окирянському $\mathrm{p}$ йон $\mathrm{x}$ ернівецької т рцизькому, рутинському i олгр дському р йон х деської обл стей є молд вські поселення. рім того, с ме в прикордонних р йон х півдня деської обл. прожив є $71 \%$ усіх болг $\mathrm{p}$ кр їни. опри те, що росіяни - н йбільш етнон ціон льн меншин кр їни, розселені вони досить дисперсно і ст новлять зн чну ч стку від н селення б г тьох обл стей, т їхня спільнот $є$ н йбільшою с ме в укр їнсько-російському прикордонні й бсолютно перев ж є в п'яти дміністр тивних р йон х риму, т кож прикордонних утивльському р-ні умської, т нично- уг нському i p снодонському р йон х уг нської обл стей. г лом сьогодні в прикордонні кр їни прожив є пон д 1 млн етнічно неукр їнського н селення. огляду н т кі особливості розселення н йбільших етнон ціон льних меншин н суч сному ет пі ці території потребують особливого підходу до координув ння їхнього регіон льного розвитку, дже економічне зрост ння т високий рівень життя є основним мотивом інтегр ції етнічно строк того н селення в з г льноукр їнське середовище.

більшості н укових пр ць, присвячених пит нням регіон льної політики, регіон ліз цію розглянуто як процес, який м є позитивні н слідки, метою регіон льного розвитку визн чено комплексний і пропорційний соці льно-економічний розвиток території. дн к для регіонів зі скл дною етнон ціон льною структурою кту льно т

(C) клярськ ., 2013 
в жливо розробляти регіон льну політику не тільки як стр тегію комплекснопропорційного розвитку, й як з сіб г рмоніз ції міжетнічних вз ємин.

зові положення держ вної регіон льної політики т проблеми щодо ії ре ліз ції відобр жені в онцепції держ вної регіон льної політики, роекті кону кр їни “ ро з с ди держ вної регіон льної політики”. гідно з цим коном, “держ вн регіон льн політик $\epsilon$ сукупністю 3 ходів, з собів, мех нізмів, інструментів т вз ємоузгоджених дій центр льних і місцевих орг нів викон вчої вл ди т орг нів місцевого с моврядув ння з метою створення повноцінного життєвого середовищ для людей н всій території кр їни т з безпечення високого рівня якості життя людини й просторової єдності держ ви т ст лого розвитку іiі регіонів” [7]. зн чені принципи держ вної регіон льної політики ст новлять універс льну прогр му розвитку для всіх обл стей кр їни, проте кожен регіон потребує конкретиз ції стр тегії з ур хув нням конкретних територі льних проблем т з питів н селення. л сне н ш мет - формулюв ння т кої прогр ми для етнічно неоднорідних р йонів укр їнського прикордоння.

тр тегія регіон льного рівня не може бути ре лізов н без з конод вчих г р нтій г рмоніз ції етнополітичного розвитку. дн к у пр вовому з безпеченні міжетнічної консолід ції існує низк прог лин. ередусім основній меті держ вної регіон льної політики - створення просторової і н ціон льної єдності - суперечить суч сн мовн політик держ ви. прикл д, з пров дження регіон льних мов, що ре лізують у регіон $\mathrm{x}$, де мову н ціон льних меншин ув ж є рідною пон д $10 \%$ н селення (у тім числі в більшості прикордонних обл стей), тільки поглибить міжетнічну б р'єрність і н довго з г льмує процес етнополітичної консолід ції в держ ві [2]. рім того, укр їнськ мов в б г тьох регіон х може зникнути 3 дміністр тивного т пед гогічного середовищ (з кон передб ч $є$, що б тьки можуть вибир ти мову н вч ння для дітей,

т кож з стосув ння регіон льних мов в дмінструктур х), посилення функцій мови н ціон льної меншини, імовірно, ктивізує деструктивні дії т сеп р тистські з клики р дик льних орг ніз цій.

жливою проблемою пр вового х $\mathrm{p}$ ктеру $є$ т кож відсутність чітких г $\mathrm{p}$ нтій єдиного гром дянств в кр їні. окрем , з коном, в кр їні можливе єдине гром дянство, одн к ун слідок пр вового з безпечення пр в н подвійне гром дянство 3 конод вчими кт ми сусідніх держ в ( горщини, умунії, осії) т з охочення своїх етнічних гром дян 3 прикордонних р йонів кр їни до відновлення гром дянств етнічної б тьківщини, ч стк біп тридів в кр їні протягом ост нніх років помітно зросл . ідповідні офіційні уст нови сусідніх держ в не н д ють інформ ції про кількість осіб з кр їни, які н були їхнього гром дянств, тому вітчизняні н уковці оперують лише приблизними неофіційними д ними. соби, що отрим ли іноземне гром дянство, згідно з положеннями кону кр їни “ ро гром дянство”, втом тично втр ч ють укр їнське, одн к н пр ктиці відстежити процес н буття іншого гром дянств дуже в жко. ільки ефективний моніторинг т з конод вче 3 кріплення пок р ння особи може вирішити проблему. осі чіткої процедури пок р ння біп тридів не визн чено, хоч ост нні пропонов ні з конопроекти 3 цього приводу містять положення про притягнення до кримін льної відповід льності чи з стосув ння штр фу до особи, як протягом визн ченого терміну не повідомил уповнов жений держ вний орг н про н буття гром дянств іншої держ ви [8].

одвійні з конод вчі ст нд рти існують щодо з безпечення пр в етнон ціон льних меншин н утворення політичної п ртії. коні кр їни “ ро об’єдн ння гром дян" (1992) з зн чено, що політичні п ртії в кр їні створені й діють тільки з всеукр - 
їнським ст тусом. одноч с кон “ ро політичні п ртії в кр їні” конкретизує порядок утворення п ртії: “...рішення м є бути підтрим но підпис ми не менше 10 тисяч гром дян кр їни, які відповідно до онституції м ють пр во голосу н вибор х, зібр ними не менш як у $2 / 3$ р йонів не менш як $2 / 3$ обл стей кр їни, міст иєв і ев стополя т рим" [4]. розуміло, що утворити п ртію т н бр ти прохідні 5 \% голосів виборців 3 політичну силу, як предст вляє будь-яку етнон ціон льну меншину (з винятком росіян), дуже в жко, зв ж ючи н кількість т специфіку розселення. ому повернення до м жорит рно-пропорційної системи розгляд ли як дієвий з сіб з безпечення виборчих пр в етнон ціон льних меншин. роте, незв ж ючи н т кі можливості предст вництв етнічних інтересів, 3 результ т ми виборів 2012 р. по м жорит рних округ х лише в окрузі, до якого включені р йони комп ктного розселення болг $\mathrm{p}$ деської обл. переміг с ме етнічний болг рин. тнічні румуни, угорці т кримські т т ри предст влені в новому п рл менті тільки з вдяки політичній співпр ці з провл дною п ртією бо популярними серед н селення опозиційними сил ми й обр ні в депут ти з п ртійними списк ми. ідт к змін виборчої системи не вирішил проблеми недост тнього політичного предст вництв н йбільших етнон ціон льних груп, дже одноч сно потрібно внести зміни до кону “ ро вибори н родних депут тів”, с ме - 3 пров дити виборчі квоти для етнон ціон льних меншин т процедуру утворення територі льних виборчих округів з огляду н розміщення ре лів комп ктного розселення етнічно неукр їнського н селення.

изик порушення політичної ст більності в регіоні є великим без єдиного суб'єкт моніторингу т усунення нег тивних тенденцій політико-геогр фічного розвитку. огляду н це кту льним пит нням є створення держ вного орг ну з викон ння концепції н ціон льної безпеки держ ви т з для відстеження сеп р тистських рухів, проведення популяриз ційної роботи серед н селення, спростув ння непр вдоподібних ф ктів, упереджених висловлюв нь про специфіку міжетнічних вз ємин в кр їні у , телеефір х. прикл д, н слідк ми політиз ції русинського руху $є$ появ в інтернет-просторі окремих публік цій про окремішність русинів т їхню дискримін цію з боку держ ви [1, 5, 6 т ін.], що ч сто переконливо звучить для гром дян, які не володіють об'єктивними історичними ргумент ми. бов'язковим з собом популяри3 ції є створення пізн в льних телепрогр м з уч стю н уковців.

г льнодерж вне зн чення для етнон ціон льної консолід ції м ють освітні з ходи, передусім збільшення кількості годин викл д ння укр їнської мови т підвищення з г льного освітнього рівня у школ х для етнон ціон льних меншин. ультурноосвітня ізоляція меншин шкодить їхній життєдіяльності т розвитку в суспільстві, дже їхні предст вники ст ють неконкурентоспроможними н освітньому і пр цересурсному ринк х держ ви. роте, н йбільш проблем поляг є в тому, що збільшення кількості годин укр їнської мови, історії, мистецтв лідери меншин чи предст вники сусідніх держ в тр ктують як дискримін цію, що н чебто суперечить чинному з конод вству.

спр вді ситу ція є неоднозн чною, дже для високого рівня зн нь укр їнської мови необхідне н лежне викл д ння предмет, одн к коли всі інші дисципліни викл д тимуть мовою н ціон льних меншин, то повноцінно укр їнської мови учні не зн тимуть.

ирішення проблем г рмоніз ції міжетнічних стосунків з лежить від оптиміз ції міждерж вних вз ємин кр їни $з$ держ в ми-сусід ми - дотрим ння $n$ ритетності і вз ємних зобов'яз нь щодо з безпечення пр в етнон ціон льних меншин. дн к н ліз протоколів з сід нь міждерж вних комісій з пит нь 3 хисту меншин свідчить про порушення цього б л нсу г р нтій, рекоменд цій і обов'язків. 


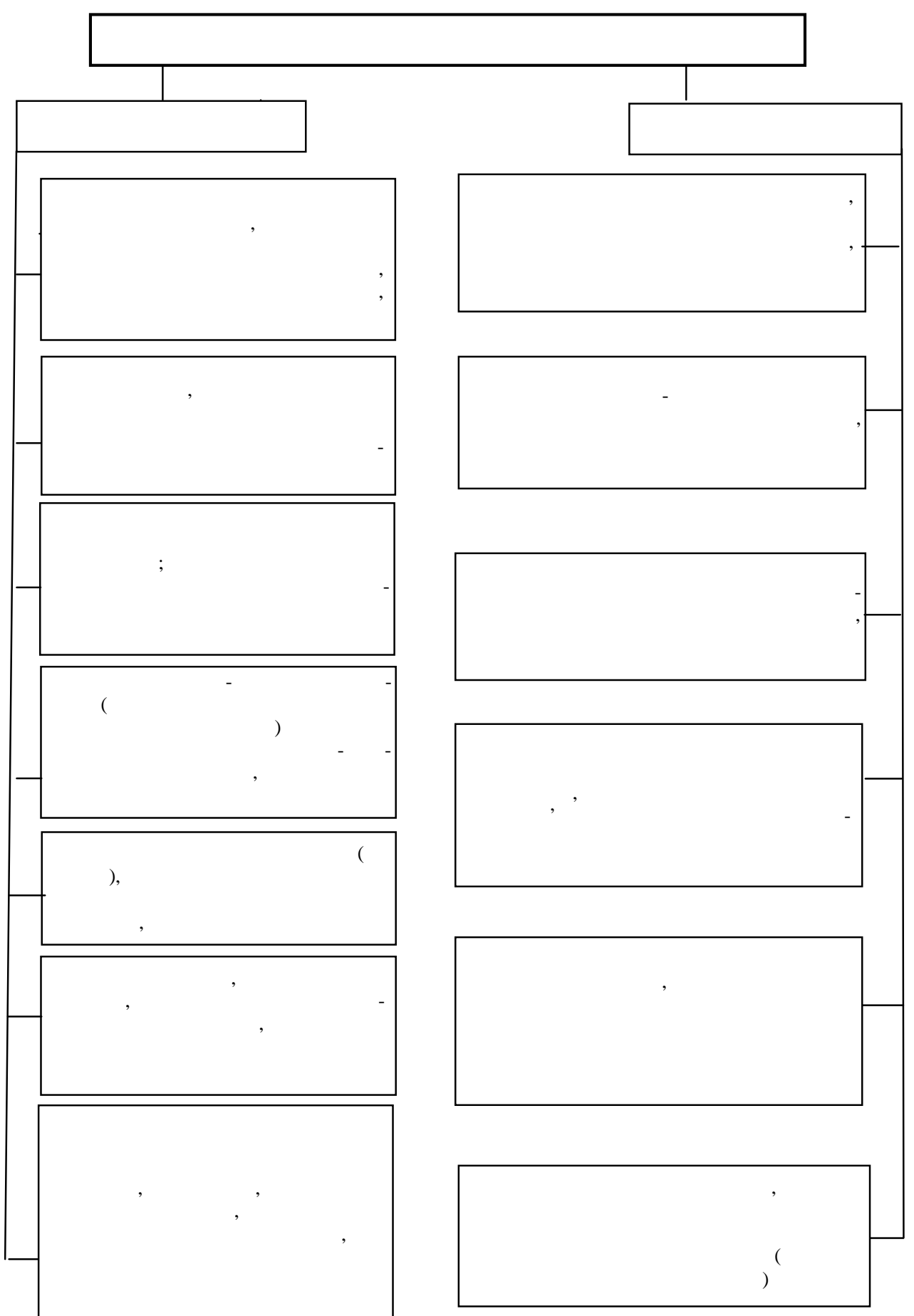

тр тегія г рмоніз ції міжетнічних вз ємин у прикордонні. 
одноч с, велик кількість пунктів-з питів з боку сусідніх держ в відповідно до протоколів м є бути фін нсов н 3 держ вного бюджету кр їни. тже, укр їнськ сторон подібними договор ми ф ктично створює всі прецеденти для м йбутніх міжетнічних суперечок, дже под льше впров дження пунктів підпис них протоколів потребує р дик льних змін у соці льно-економічній, культурно-освітній сфер х суспільств . ому необхідний попередній н уковий н ліз усіх положень подібних договорів з прогнозув нням м йбутніх н слідків щодо їхньої ре ліз ції.

онкретиз ція з ходів г рмоніз ції етнополітичного розвитку держ вного м сшт бу відбув ється н місцевому рівні (див. рисунок). н логічно до принципів з конод вчого з безпечення регіон льної політики т геоетнополітики, прогр ми обл сного розвитку, які розробляють н місцях, м ють бути укл дені в р мк х єдиної концепції - інтегрув ння регіону в $з$ г льноукр їнське середовище. он зовсім не з перечує кту льності ідеї н д ння більших повнов жень місцевим р д м як результ ту децентр ліз ції вл ди. деться про синхронізов не впров дження цих двох принципів у $\mathrm{p}$ мк х єдиної онцепції регіон льного розвитку. томість у б г тьох прикордонних обл стях, зокрем ернівецькій, деській, уг нській, основним дискусійним пит нням у процесі розроблення онцепції регіон льної політики є н д ння обл сті ст тусу території пріоритетного розвитку, предст вники еліти угорської меншини чи русинських ктивістів розгляд ють регіон льний розвиток к рп тської обл. тільки в контексті отрим ння втономії. е ліз ція подібних умовностей - передумов для територі льної поляриз ції і ч сто є проект ми осіб, нез цік влених в укр їнському векторі політичної інтегр ції регіону.

еличезною проблемою з лиш ється відд леність і депресивність окремих прикордонних $\mathrm{p}$ йонів. пособ ми іï подол ння $є$ перерозподіл коштів місцевого бюджету н користь т ких територій, т кож зрост ння соці льно-культурного, економічного й дміністр тивного зн чення р йцентрів для нівелюв ння нег тивного впливу периферійності н життєдіяльність н селення. днією з умов зрост ння може бути розроблення т ре ліз ція концепції етнокультурного туризму.

ирішення н явних т можливих нег тивних тенденцій політико-геогр фічного розвитку в етнічно неоднорідних прикордонних $\mathrm{p}$ йон $\mathrm{x}-3$ гроз сеп р тизму, внутрішньообл сної територі льної поляриз ції, формув ння політично інертних зон 3 н дмірно низькою політичною ктивністю н селення, яке підд ється м ніпулюв нню суб'єктивними вплив ми тощо - з лежить від ефективної ре ліз ції усіх розглянутих положень пропонов ної стр тегії. ріоритетною умовою впров дження пунктів єдиної стр тегії г рмоніз ції етнополітичних процесів $є$ позитивні системні зрушення в усіх сфер х життєдіяльності.

1. одьм $u$. нтирусинський “бумер нг” м $є 3$ зн ти фі ско [ лектронний ресурс] / . одьм ш // . орум підк рп тських русинів. - ежим доступу: http://rusin.forum24.ru/?1

2. кон кр їни ро з с ди держ вної мовної політики [ лектронний ресурс]. ежим доступу: http://rada.gov.ua/pls/zweb2/ webproc4_1? pf3511=41018

3. кон кр їни “ ро об'єдн ння гром дян” / . - . : рл ментське в-во, 1998. 15 с. ( ерія “ кони кр їни”: од ток до щотижневик “ ідомості ”).

4. кон кр їни “ ро політичні п ртії в кр їні”/ ідомості , 2001. - . 118. 
5. елег нич . . собливості регулюв ння проблеми політичного русинств н к рп тті [ лектронний ресурс] / . . елег нич // уковий вісник ім. св. ирил і ефодія, ім. . олошин . - ежим доступу: http://www.teologia.org.ua/mapa-saietu-1.html

6. игович. усини в кр їні : ст тус, проблеми т перспективи [ лектронний pecypc] / в н игович // іче. - 2009. - № 7 . - ежим доступу: http://www.viche.info/journal/1391

7. ро онцепцію держ вної регіон льної політики [ лектронний ресурс]. - ежим доступу: http:// zakon 1.rada.gov.ua//cgi-bin /laws/ main. chi?nreg=341

8. роект кону про внесення змін до кону кр їни “ ро гром дянство кр їни” (щодо усунення колізій, які дозволяють подвійне гром дянство) [ лектронний ресурс]. - ежим доступу: http://w1.c1.rada.gov.ua/pls/zweb_n/webproc4_2?pf3516=2752

\author{
m ття: н дійшл до ред киї̈ 18.12.2012 \\ доопр иьоов н 10.04.2013 \\ прийнят до друку 16.05.2013
}

\title{
TASK OF REGIONAL POLI Y IN BOUNDARY ETHNICALLY HETEROGENEOUS REGIONS OF UKRAINE
}

\author{
Oksana Sklyarska \\ Ivan Franko National University of Lviv, \\ P. Doroshenko Str., 41, UA - 79000 Lviv, Ukraine
}

The concepts of state regional politics in order to integrate national minorities into naonwide environment have been substantiated in the article. The strategy of harmonisation of ethnic political relations has been reviewed.

Key words: regional politics, frontier districts, ethnic political relations, integration into nationwide environment.

кс н клярск я

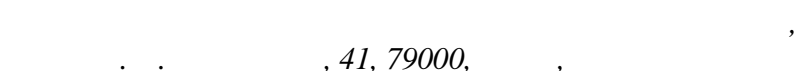

боснов но основы регион льной политики с целью интегр ции этнически неоднородного н селения погр ничных регионов в общеукр инскую среду. зр бот но стр тегию г рмониз ции этнополитических отношений в погр ничных р йон х.

лючевые слов : регион льн я политик, погр ничные р йоны, межэтнические отношения, интегр ция в общеукр инскую среду. 